\title{
Pertumbuhan Bibit Cabai pada Media Serbuk Gergaji Kayu Sengon dengan Perendaman Air
}

\author{
Rabbani Hario Langgeng ${ }^{1}$, Etik Wukir Tini ${ }^{2}$, Budi Prakoso ${ }^{3}$ \\ 1-3Department of Agrotechnology, Faculty of Agriculture, Universitas Jendral Soedirman, Purwokerto, Indonesia
}

${ }^{*}$ Corresponding Author:

E-mail: etik.unsoed@gmail.com

Received 27 May 2019; Accepted 24 June 2019; Published 30 December 2019

\begin{abstract}
The purpose of this research was to know the correct soaking period of sawdust media and growth of red chili seedling. This research was conducted at the screen house of the Faculty of Agriculture, University of Jenderal Soedirman, Banyumas, from April-May 2019. The method used was Randomized Completely Block Design. The treatments were consisted of media containing soil, sawdust without soaking, sawdust that has been soaked for 1 day, sawdust that has been soaked for 2 days, sawdust that has been soaked for 3 days, sawdust soaked for 4 days, sawdust that has been soaked for 5 days, sawdust that has been soaked for 6 days, sawdust that has been soaked for 7 days. Observed variables included plant height 14 days, root length, number of leaves, leaf length, leaf width, plant height 42 days. The results showed that germination and growth of seedlings of chili plants on sawdust media that had been soaked for 7 days had better plant height, root length, number and length of leaves than on soil media.
\end{abstract}

(C) 2019 Agrotechnology Research Journal

Keywords: Electrical Conductivity; Seedlings; Waste Media

Cite This As: Langgeng RH, Tini EW, Prakoso B. 2019. Pertumbuhan Bibit Cabai pada Media Serbuk Gergaji Kayu Sengon dengan Perendaman Air. Agrotech Res J 3(2): 97-102. https://doi.org/10.20961/agrotechresj.v3i2.34421

\section{PENDAHULUAN}

Cabai merah (Capsicum annuum L.) merupakan tanaman hortikultura penting di Indonesia dengan nilai ekonomi tinggi dan banyak dimanfaatkan dalam bidang pangan. Cabai merah mampu memenuhi kebutuhan khas masyarakat Indonesia akan rasa pedas dari suatu masakan (Setiadi 2005). Hal ini menyebabkan tingkat permintaan cabai tinggi. Benih merupakan penentu kualitas produksi cabai. Penggunaan benih unggul dapat menghasilkan produk yang baik dan berkualitas (Wahyudi 2016). Media tanam merupakan faktor penting pertumbuhan tanaman. Media tanam yang baik dapat ditemukan pada tanah dengan tata udara dan air yang baik, mempunyai agregat mantap, kemampuan menahan air yang baik dan ruang untuk perakaran yang cukup. Namun, Penggunaan media tanah sebagai media persemaian masih memiliki beberapa kelemahan, di antaranya media menjadi padat karena sedikit kandungan bahan organik, aerasi kurang baik, dan rendahnya unsur hara (Agustin 2014).

Limbah industri menjadi salah satu persoalan penting saat ini, sehingga diperlukan solusi pengelolaan limbah.

This is an open access article

Licensed under the Creative Commons Attribution International License CC-BY-SA 4.0

(cc) BY-SA
Menurut Sutarman (2016) bahwa belum ada penanganan dan pemanfaatan limbah secara terpadu supaya bermanfaat. Penanganan limbah serbuk gergaji selama ini dengan dibakar. Pembakaran limbah akan menimbulkan asap dan emisi $\mathrm{CO}_{2}$ yang membahayakan lingkungan (Wardani 2017). Penggunaan kayu sengon yang tidak sedikit sebagai bahan bangunan dan peralatan rumah tangga akan menimbulkan limbah yang berupa serbuk gergaji. Sejauh ini limbah tersebut belum dimanfaatkan secara maksimal. Serbuk gergaji sisa dari kayu sengon biasanya digunakan untuk media penanaman jamur tiram karena serbuk kayu sengon termasuk kayu keras dan tidak mengandung getah (Reyeki 2013). Penggunaan limbah serbuk gergaji memiliki dampak positif bagi lingkungan. Serbuk gergaji merupakan biomassa yang belum termanfaatkan secara optimal meskipun ketersediaannya tinggi. Upaya pemanfaatan limbah serbuk gergaji dapat diolah menjadi bahan media tanam, sehingga dapat mengurangi pencemaran lingkungan (Agustin 2014). Penelitian ini bertujuan mengetahui lama perendaman media tanam serbuk gergaji yang tepat terhadap persemaian benih dan pertumbuhan bibit cabai merah.

\section{BAHAN DAN METODE}

Penelitian dilaksanakan di screen house Fakultas Pertanian Universitas Jenderal Soedirman, Banyumas, pada bulan April 2019 sampai bulan Mei 2019. Penelitian 
terdiri atas dua tahap. Rancangan percobaan yang digunakan yaitu Rancangan Acak Kelompok (RAK). Perlakuan terdiri atas media: $\mathrm{K}=$ Tanah (Kontrol), $\mathrm{P0}=$ serbuk gergaji (Tanpa direndam), P1 = Serbuk gergaji yang sudah direndam selama 1 hari, P2 = Serbuk gergaji yang sudah direndam selama 2 hari, P3 = Serbuk gergaji yang sudah direndam selama 3 hari, P4 = Serbuk gergaji yang sudah direndam selama 4 hari, P5 = Serbuk gergaji yang sudah direndam selama 5 hari, $P 6=$ Serbuk gergaji yang sudah direndam selama 6 hari, P7 = Serbuk gergaji yang sudah direndam selama 7 hari. Bahan dalam penelitian meliputi bibit cabai merah, serbuk gergaji, tanah, larutan $A B$ Mix, dan air. Alat yang digunakan dalam penelitian meliputi polybag, plastik terpal, penggaris, alat tulis, buret, labu erlenmeyer, Electrical Conductivity (EC) meter, $\mathrm{pH}$ meter.

Tahap penelitian pertama adalah persemaian benih cabai pada media semai dari serbuk gergaji yang sudah direndam air selama 0, 1, 2, 3, 4, 5, 6, 7 hari dan tanah. Tahap penelitian pertama terdiri atas 9 perlakuan dengan 1 ulangan. Satu unit percobaan terdiri dari 1 tray dengan 100 lubang tanam, setiap lubang terdiri dari 1 tanaman. Variabel yang diamati meliputi tinggi tanaman 14 HST, dan panjang akar tanaman 14 HST. Tahap penelitian kedua adalah pertumbuhan bibit cabai pada media tanam dari serbuk gergaji yang sudah direndam air selama $0,1,2,3,4,5,6,7$ hari dan tanah dengan 3 kali ulangan. Dalam satuan percobaan terdiri dari 5 polybag, setiap polybag terdapat satu tanaman dengan volume media 0,18 liter. Dengan demikian terdapat total 135 populasi tanaman. Variabel yang diamati pada tahap kedua meliputi jumlah daun 42 HST, panjang daun 42 HST, lebar daun 42 HST, dan tinggi tanaman 42 HST. Data yang diperoleh dianalisis menggunakan analysis of variants (ANOVA) dan apabila berbeda nyata dilakukan Duncan Multiple Range Test (DMRT) dengan taraf kesalahan $5 \%$.

\section{HASIL DAN PEMBAHASAN}

$\mathrm{pH}$ dan konduktivitas listrik media penelitian (Tabel 1). Hasil penelitian menunjukkan bahwa semakin lama perendaman media serbuk gergaji maka $\mathrm{pH}$ semakin mendekati netral dan $\mathrm{pH}$ tanah yang digunakan sebagai media kontrol sebesar 6. Hasil ini sesuai dengan Hardjowigeno (2007) yaitu $\mathrm{pH}$ tanah umumnya berkisar dari 3,0-9,0, tapi di Indonesia umumnya tanahnya bereaksi masam dengan $\mathrm{pH}$ 4,0- 5,5 sehingga tanah dengan $\mathrm{pH}$ 6,0-6,5. Berdasarkan hasil pengukuran konduktivitas listrik menggunakan EC meter bahwa semakin lama media di rendam maka konduktivitas listrik semakin turun. Menurut Rosliani dan Sumarni (2005), setiap jenis dan umur tanaman membutuhkan larutan dengan konduktivitas listrik yang berbeda-beda. Kebutuhan konduktivitas listrik disesuaikan dengan fase pertumbuhan, yaitu ketika tanaman masih kecil, konduktivitas listrik yang dibutuhkan juga sedikit dan semakin meningkat umur tanaman semakin besar konduktivitas listrik yang dibutuhkan. konduktivitas listrik yang dibutuhkan untuk sayuran daun pada fase vegetatif yaitu 2,0-,2,5.
Tabel 1. Hasil pengukuran $\mathrm{pH}$ dan konduktivitas listrik

\begin{tabular}{lcc}
\hline Perlakuan & $\mathrm{pH}$ & Konduktivitas listrik \\
\hline Kontrol & 6,0 & 0,48 \\
Rendam 0 hari & 6,2 & 0,70 \\
Rendam 1 hari & 4,2 & 1,03 \\
Rendam 2 hari & 5,3 & 0,71 \\
Rendam 3 hari & 5,5 & 0,58 \\
Rendam 4 hari & 5,6 & 0,54 \\
Rendam 5 hari & 5,7 & 0,51 \\
Rendam 6 hari & 5,9 & 0,53 \\
Rendam 7 hari & 5,9 & 0,57 \\
\hline
\end{tabular}

Berdasarkan hasil penelitian bahwa pertumbuhan kecambah benih sesuai dengan yang terdapat pada label kemasan cabai yaitu $85 \%$. Persentase kecambah terendah yaitu $88 \%$ pada media tanah. Penggunaan media serbuk gergaji dengan perendalam 4 dan 5 hari menghasilkan persentase kecambah tertinggi yaitu 95\%. Menurut Sutopo (2000), media menjadi salah satu faktor penting yang mempengaruhi perkecambahan, media yang digunakan harus mempunyai sifat fisik yang baik, gembur, mempunyai kemampuan menyimpan air dan bebas dari organisme penyebab penyakit.

Tabel 2. Persentase benih yang berkecambah

\begin{tabular}{lc}
\hline Perlakuan & $\begin{array}{c}\text { Persentase Benih yang } \\
\text { Berkecambah (5) }\end{array}$ \\
\hline Kontrol (Tanah) & 88 \\
Rendam 0 hari & 89 \\
Rendam 1 hari & 94 \\
Rendam 2 hari & 93 \\
Rendam 3 hari & 93 \\
Rendam 4 hari & 95 \\
Rendam 5 hari & 95 \\
Rendam 6 hari & 91 \\
Rendam 7 hari & 94
\end{tabular}

\section{Pengaruh media tanam terhadap persemaian cabai Tinggi tanaman 14 HST}

Hasil penelitian menunjukkan bahwa lama media tanam berpengaruh sangat nyata terhadap pertumbuhan tinggi tanaman pada umur 14 HST. Perlakuan perendaman media selama 7 hari lebih tinggi dibandingkan dengan perlakuan perendaman media selama 1, 2, 5, dan 3 hari tapi tidak berbeda dengan perendaman media selama 0,6 , dan 4 hari. Tinggi tanaman pada penggunaan media tanam sebesar 2,22 $\mathrm{cm}$. Media serbuk gergaji dengan perendaman 7 hari memiliki hasil yang lebih tinggi $(2,66 \mathrm{~cm})$, diikuti dengan perlakuan perendaman media selama 4 hari $(2,55 \mathrm{~cm})$ hal ini membuktikan bahwa kandungan hara yang terdapat di media serbuk gergaji yang telah direndam selama 7 hari mampu menyediakan unsur hara yang cukup bagi pertumbuhan tinggi saat persemaian. Menurut Sari (2015), dari pertumbuhan tanaman cabai yang tumbuh pada media serbuk gergaji memiliki pertumbuhan yang lebih rendah. Penyebabnya yaitu pada serbuk gergaji terdapat lignin yang dapat menghambat proses penguraian media tanam. Sehingga ketersediaan unsur hara tidak memenuhi. Diduga perolehan unsur yang dibutuhkan untuk pertumbuhan tanaman didapat dari larutan nutrisi yang cukup, sehingga pertumbuhannya baik. Perendaman media serbuk gergaji juga menjadi faktor pertumbuhan yang baik. Dengan perlakuan perendaman kandungan tanin pada media serbuk gergaji semakin sedikit. Perlakuan pencucian yang diberikan dapat mengurangi kadar tanin pada serbuk gergaji. Tanin pada serbuk gergaji bersifat anutrisi bagi pertumbuhan tanaman dan juga menghambat kerja enzim (Imelda 2015). 


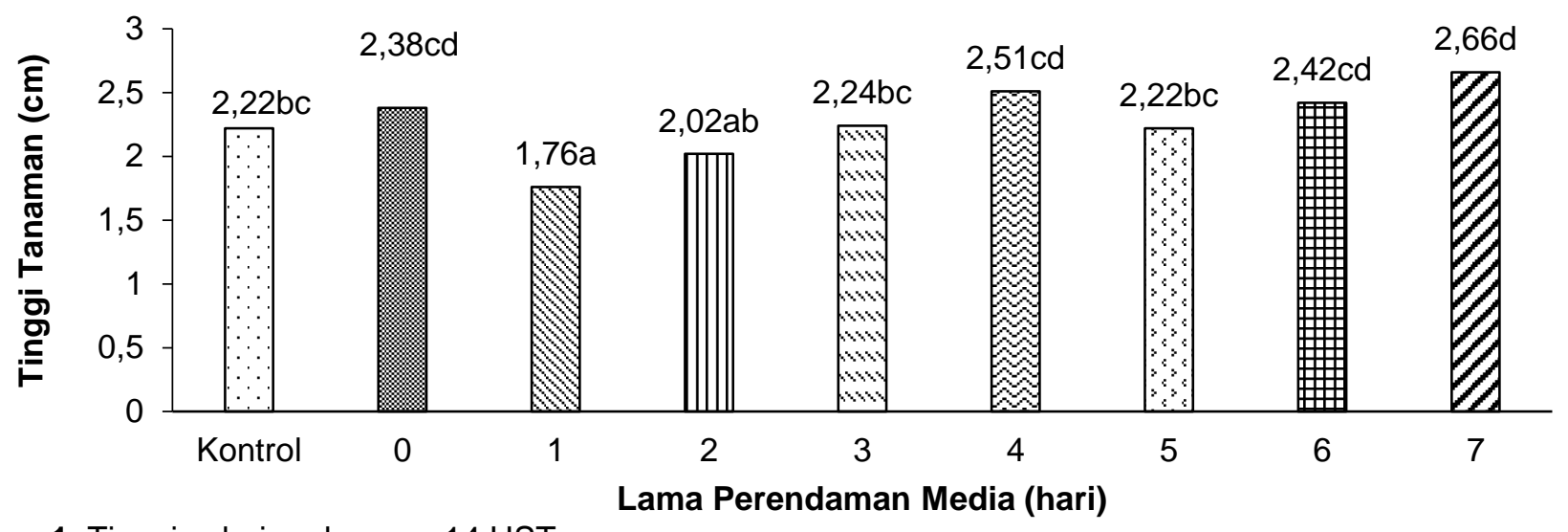

Gambar 1. Tinggi cabai pada umur 14 HST

\section{Panjang akar 14 HST}

Perendaman media berpengaruh nyata terhadap pertumbuhan akar cabai (Gambar 2). Pertumbuhan akar cabai di media serbuk gergaji yang direndam selama 5 dan 6 hari (P5 dan P6) lebih panjang daripada yang tumbuh di media dengan perlakuan lainnya. Pertumbuhan terendah terdapat pada media serbuk gergaji yang tidak direndam (P0). Diduga pertumbuhan akar sangat dipengaruhi oleh keadaan fisik media tanamnya. Panjang akar pada media tanah hanya $2,44 \mathrm{~cm}$. Adanya pemadatan tanah, akan menyebabkan struktur tanah dan pori-pori tanah, sehingga kandungan air tanah ikut berubah. Tanah merupakan tempat berkembangnya akar pohon serta interaksi hara dengan pohon, maka pemadatan tanah dan kandungan air tanah akan mempengaruhi pertumbuhan akar pohon (Rusdiana 2000). Penelitian serupa menunjukkan pertumbuhan panjang akar pada tanaman cempaka kuning pada media serbuk gergaji menunjukkan hasil yang cukup baik meskipun tidak maksimal. Pertumbuhan panjang akar sangat dipengaruhi oleh banyaknya pori pada media. Sebaliknya jika bibit ditanam dalam media yang terlalu padat, aerasi dan porositas kecil, maka media akan sulit ditembus akar, dan daerah pemanjangan akar semakin pendek (Agustin 2014).

\section{Pengaruh media tanam terhadap pertumbuhan cabai Jumlah daun 42 HST}

Media tanam berpengaruh nyata terhadap pertumbuhan daun cabai. Media serbuk gergaji dengan perendaman selama 7 hari menunjukkan hasil pertumbuhan daun yang sangat baik. jumlah daun pada media tanah terendah yaitu 5,33 helai. Hasil penelitian Sari (2015), menunjukkan bahwa pertumbuhan jumlah daun yang menggunakan media serbuk gergaji dan tanah menjadi yang terendah pertumbuhannya dibanding media yang mengandung campuran tanah dengan sekam padi dan tanah dengan serabut kelapa, namun pertumbuhan pada media yang mengandung serbuk gergaji dan pada media tanah tidak berbeda. Pertumbuhan yang lambat pada media yang mengandung serbuk gergaji disebabkan yaitu saat pengomposan tidak seluruh komponen serbuk gergaji dirombak dengan sempurna sehingga ketersediaan unsur hara yang optimal tidak terpenuhi bagi tanaman. Diduga pertumbuhan jumlah daun pada media serbuk gergaji lebih baik dibanding media tanah diduga karena unsur hara yang terdapat pada media serbuk gergaji masih mampu mencukupi kebutuhan tanaman melalui larutan nutrisi yang sudah diberikan berupa $A B$ mix. Proses dekomposisi pada media serbuk gergaji yang melibatkan mikroba tidak berpengaruh terhadap ketersediaan hara. Menurut Pratiwi (2019), lama pengomposan juga berpengaruh pada jumlah daun tanaman kubis bunga, hal ini berhubungan dengan waktu mikroba dalam melakukan dekomposisi. Selain itu perendaman dapat melarutkan tanin, sehingga tidak menghambat kerja enzim. Berkurangnya kadar tanin pada media serbuk gergaji dapat melalui perlakuan pencucian. Tanin memiliki sifat yang mudah larut dengan air. Tanin dapat mengikat selulosa, pektin, alkaloid dan menghambat kerja enzim karena daya ikatnya tersebut (Imelda 2015).

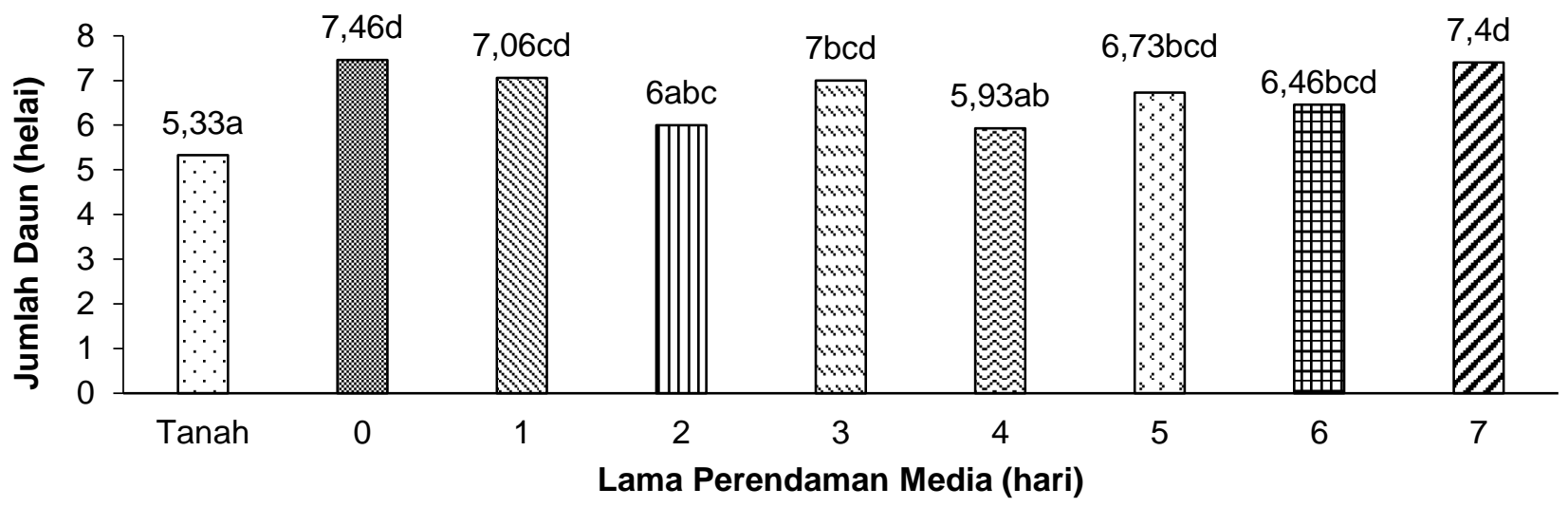

Gambar 2. Panjang akar cabai umur 14 HST 




Gambar 3. Jumlah daun cabai umur 14 HST

\section{Panjang daun 42 HST}

Media tanam berpengaruh nyata terhadap pertumbuhan panjang daun. Media serbuk gergaji tanpa perendaman dan media serbuk gergaji yang direndam selama 7 hari memiliki pertumbuhan panjang daun yang lebih panjang dibandingkan perlakuan lainnya. Pertumbuhan panjang daun yang terendah terdapat pada media yang direndam selama 6 hari. Media yang direndam selama 7 hari memiliki rata-rata panjang daun $2,74 \mathrm{~cm}$ dan media yang tidak direndam memilik rata-rata panjang daun 2,88 cm. Menurut Winarti (2017), bahwa jenis media tanam serbuk gergaji dengan penambahan pupuk berbeda nyata terhadap jumlah, lebar, dan panjang daun bibit Anggrek Cattleya sp. Serbuk gergaji merupakan bahan organik yang sedikit mengandung natrium $(N)$, fosfor $(P)$, kalium $(K)$, dan magnesium $(\mathrm{Mg})$ dengan kapasitas pengikat air baik meskipun relatif sukar didekomposisi karena adanya senyawa lignin, minyak, lemak dan resin yang tersusun oleh senyawa yang sulit dirombak menjadi senyawa yang lebih sederhana, dengan demikian kandungan unsur $\mathrm{P}$ yang tersedia lebih sedikit. Diduga umur tanaman yang masih muda maka kebutuhan unsur hara tidak terlalu tinggi sehingga pertumbuhan panjang daun dapat terpenuhi oleh unsur yang hara yang tersedia dari pemberian pupuk. Menurut Prajwalita (2018), pertumbuhan tanaman pada media yang mengandung serbuk gergaji tidak terhambat karena umur tanaman yang masih muda, sehingga kebutuhan hara tidak terlalu tinggi. Pemberian pupuk masih mencukupi kebutuhan tanaman.

\section{Lebar daun 42 HST}

Media tanam tidak berpengaruh nyata terhadap pertumbuhan lebar daun. Penggunaan media serbuk gergaji dengan lama perendaman 7 hari (P7) lebih baik pertumbuhannya kemudian selanjutnya diikuti oleh media dengan perendaman selama 0 dan 1 hari ( $P 0$ dan $\mathrm{P} 1)$. Pertumbuhan lebar daun terendah ditunjukkan oleh lama perendaman media selama 3 dan 4 hari (P3 dan P4), sedangkan lebar daun pada media tanah juga rendah yaitu hanya $1,04 \mathrm{~cm}$. Menurut Winarti (2017), bahwa jenis media tanam serbuk gergaji dengan penambahan pupuk berbeda nyata terhadap jumlah, lebar, dan panjang daun bibit Anggrek Cattleya sp. Jenis media yang paling baik untuk pertumbuhan lebar daun masa vegetatif anggrek Cattleya sp. adalah serbuk gergaji dan ampas tebu. Diduga pemberian larutan nutrisi $A B$ mix dengan konsentrasi yang sama memberikan pertumbuhan yang tidak berbeda.

\section{Tinggi tanaman umur 42 HST}

Pertumbuhan tinggi tanaman pada umur 42 HST menunjukkan tidak berbeda nyata. Penggunaan media tanah serbuk gergaji dengan perendaman 0 hari dan 7 hari menunjukkan pertumbuhan tertinggi. Pertumbuhan tinggi tanaman terendah terdapat pada media serbuk gergaji yang direndam 6 hari (P6). Diduga pertumbuhan tinggi tanaman 42 HST tidak berbeda dikarenakan larutan nutrisi yang diberikan tidak berbeda konsentrasinya. Menurut Sari (2015), pertumbuhan tinggi tanaman cabai rawit dari media yang mengandung serbuk gergaji memiliki pertumbuhan yang lebih rendah. Penyebabnya yaitu serbuk gergaji sebagai bahan baku kompos, bernilai sedang hingga baik namun tidak seluruh komponen dari bahan serbuk gergaji dapat dirombak dengan sempurna. Lignin pada serbuk gergaji dapat menghambat proses penguraian media tanam sehingga ketersediaan unsur hara yang optimal tidak terpenuhi bagi tanaman.

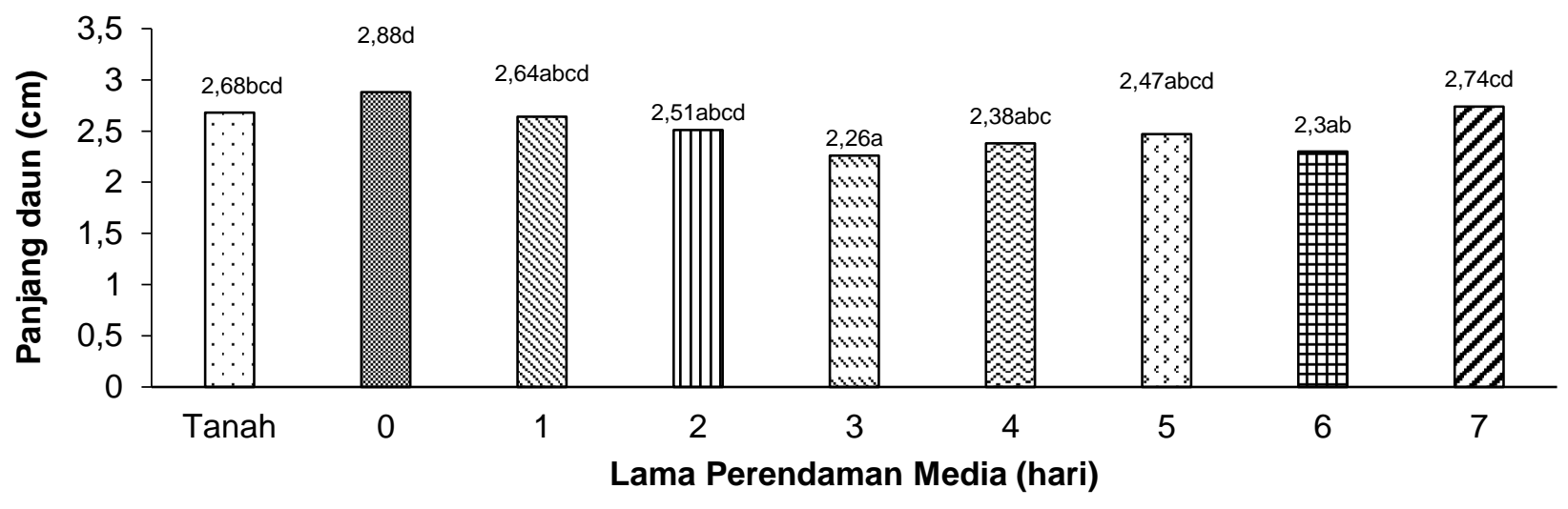

Gambar 4. Panjang daun cabai 




Gambar 5. Lebar daun tanaman cabai



Gambar 6. Tinggi tanaman cabai umur 42 HST

\section{KESIMPULAN}

1. Media serbuk gergaji kayu sengon dengan perendaman 7 hari pada persemaian memberikan pengaruh terbaik terhadap pertumbuhan tinggi tanaman cabai sebesar 2,66. Media serbuk gergaji dengan perendaman 5 hari memberikan pengaruh terbaik terhadap pertumbuhan panjang akar tanaman cabai sebesar $6,08 \mathrm{~cm}$.

2. Media serbuk gergaji dengan perendaman 7 hari pada pembibitan memberikan pengaruh terbaik terhadap pertumbuhan jumlah, panjang dan lebar daun.

3. Perendaman media serbuk gergaji kayu sengon dengan air dapat dilakukan supaya pertumbuhan bibit tanaman cabai lebih baik

\section{DAFTAR PUSTAKA}

Agustin AD, Riniarti M. 2014. Pemanfaatan Limbah Serbuk Gergaji dan Arang Sekam Padi Sebagai Media Sapih untuk Cempaka Kuning (Michelia champaca). Jurnal Sylva Lestari 2(3): 49-58.

Hardjowigeno S. 2007. IImu Tanah. Akademika Presindo. Jakarta.

Imelda N, Periadnadi. 2015. Pengaruh Pencucian Media Serbuk Gergaji Terhadap Keberadaan dan Aktivitas Beberapa Enzim Media dan Tubuh Buah Jamur Tiram Putih. Jurnal of Natural Science 4(3): 310-321.

Prajwalita DT. 2018. Pertumbuhan Bibit Pepaya Varietas Callina Pada Empat Jenis Media Tanam yang Diberi
Pupuk AB-mix Dengan Dosis Berbeda. Skripsi. Universitas Jendral Soedirman, Purwokerto.

Pratiwi SH, Purnamasari RT. 2019. Pengaruh Lama Pengomposan Serbuk Gergaji Kayu Jati dan Dosis EM4 Terhadap Pertumbuhan dan Hasil Tanaman Kubis Bunga (Brassica oleracea L.) Dataran Rendah. Buana Sains, 18(2): 139-148.

Reyeki S. 2013. Pemanfaatan Serbuk Gergaji Kayu Sengon (Albizia falcataria) dan Bekatul Sebagai Media Tanam Budidaya Jamur Tiram Putih (Pleurotus ostreatus) Dengan Penambahan Serbuk Sabut Kelapa (Cocos nucifera). Thesis. Universitas Muhammadiyah Surakarta.

Rosliani R, Sumarni N. 2005. Budidaya Tanaman Sayuran Dengan Sistem Hidroponik. Balai Penelitian Tanaman Sayuran, Bandung.

Rusdiana O, Fakuara Y, Kusmana C, Hidayat Y. 2000. Respon Pertumbuhan Akar Tanaman Sengon (Paraserianthes falcataria) Terhadap Kepadatan dan Kandungan Air Tanah Podsolik Merah Kuning. Jurnal Manajemen Hutan Tropika 6(2): 43-53.

Sari E, Fantashe D. 2015. Pengaruh Jenis Media Tanam Terhadap Pertumbuhan Vegetatif Tanaman Cabai Rawit (Capsicum frutescens L.). Bio-Lectura: Jurnal Pendidikan Biologi 2(2): 129-139.

Sutarman IW. 2016. Pemanfaatan Limbah Industri Pengolahan Kayu di Kota Denpasar (Studi Kasus Pada CV Aditya). Jurnal PASTI X(1): 15 - 22. 
Sutopo L. 2000. Teknologi Benih. Rajawali Press. Jakarta.

Wahyudi I, Abror M. 2016. Pengaruh Tinggi dan Jenis Bahan Naungan Pembibitan Terhadap Vigor Cabai Merah Besar (Capsicum annum L.). NABATIA 11(1): 1-10.

Wardani RAK, Sari DP. 2017. Pemanfaatan Limbah Gergaji Kayu Sebagai Media Tanam Jamur dan Kain Perca untuk Bahan Baku Dalam Packaging
Fung-cube. In Proceeding Biology Education Conference: Biology, Science, Environmental, and Learning 14(1): 83-87.

Winarti. 2017. Inovasi Media Tanam Dari Ampas Tebu dan Serbuk Gergaji untuk Menumbuhkan Bibit Anggrek (Cattleya sp.) Pada Tahap Aklimatisasi dengan Pupuk Gandasil D. Skripsi. Universitas Nusantara PGRI, Kediri. 